\title{
A NOTE ON THE SIGNIFICANCE OF SINTHETIC FUELS AND THE ROLE OF NUCLEAR ENERGY AS A SOURCE OF SUPPLY
}

\author{
Meyer Steinberg \\ Department of Applied science \\ Brookhaven National Laboratory \\ Upton, I.I.e N.Y.
}

Informal Report

June 1975

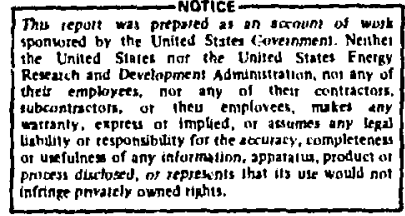

This work was performed under the auspices of the $U$. $S$. Energy Research and Development Administraiion.

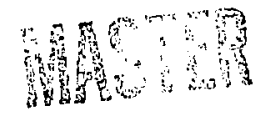




\section{A Note on the Signiflcance of Synthetic Fuels and the Role of Nuciear Energy as A Source of Supply}

by

Meyer Steinberg

Department of Applied Science

Brookhaven National Laboratcizy

Up ton, L.I., N.Y.

June 1975

The reasons tr $\geqq$ subject of synthetic fuels is of importance are several-fold. First, the U.S. energy economy is largely dominated by the end-use consumption of thermal energy in the form of liquid and gaseous fuels, petroleum and natural gas. It has been estimated by some that even in the year 2000 the consumption of electrical puwer will only make up 10\% of the total energy consumed in the country. Thus, the argument put forth by fossil energy developers is that even if all the electrical energy were generated by nuclear, $90 \%$ would still have to be supplied by fossil fuel. Cf course, this is somewhat distorted because it does not take into account the thermal to electrical energy conversion efficiency. Even so, the total energy supplied for conversion te electrical power would be $25 \%$ which is still a smaller fraction of the total energy budget and allnws the fossil fuel developer to argue that more R\&D funds should be put into fossil energy and less into nuclear. However, this thinking is still erroneous because it neglects to recognize two possibilities; one is that nuclear energy can be used to generate synthetic fuels either to extend the supply of the fossil fuel reserve or to completely replace its use and the other is that the economy would convert more to the use of electrical energy. However, even the mor:- optimistic proponents of the 
"all-electric economy" do not foresee a higher consunption than $50 \%$ of the total energy consumption in the begitaing of the 218 t Century. The problems of efficiency, losses and storage of electrical energy are important restraints in shifting to the all-electric econowy. This leaves then a significant requirement for utilization of liquid and gaseous fuels. The emphasis on liquid and gaseous fuels as opposed to solid fuel is based on its convenience of transporting, storage and efficiency of utilization in thermal power convertors and devices.

The second argument for synthetic liquid and 1iquid fuels is well known, in that world natural sources of liquid and gaseoul fuels, petroleum and natural gas, is limited and estimated to be fast declining. Natural gas is expected to last no more than about 20 to 30 years and petroleum no more than about 75 years. The curves for supply versus consumption are beginning to decline even now. The third realization is that the U.S. resources for petroleum and natural gas are even more limited and that we rely on foreign Emports to a significant extent (15-20\% of total energy) with increasing outlays of capital. Thus, the impetus to provide for synthetic liquid and gaseous fuels in the U.S. Is well founded.

An examination of sources of synthetic liquid and gaseous fuels indicates that these can be produced from at least five sources: (1) Coal, (2) agricultural products, (3) solar energy, (4) waste, urban and agr1cultural, and (5) nuclear. - These resources can be used singly or in combination in one or more processes. Coal is abundant in the U. S. and estimated to last at least several hundred years. The problem with coal is its environmental and safety hazards including extracting it from the ground and in its transportation and utilization. However, it 
is available. Agricultural products are really based on the utilization of solar energy. Some people believe that energy farms could be developed. However, the inherent low intensity of solar energy deposition requires that large tracts of land are needed and the process is inefficient (not more than severz.l percent) and time consuming. Direct solar enegy either through absorbers or photovoltaic systens suffer from low efficiency, low intensity, high costs and reliability. However, developments should proceed to overcome these difficulties. Urban waste is limited (5-10\% of the total energy economy) ilit should be included wherever possible because it serves a double purfose of waste disposal and energy recovery. Agricultural waste has great potential but suffers from similar problems as the agricultural products with the added problem of collection and transportation from widely scattered areas. Nuclear, elther fission or fusion, can produce the intensity and capacity for a synthetic liquid and gaseous synthetic fuel industry, provided the problems of technology and hazards are solved.

Looking at the impact that various sources of liquid and gaseous fuels can make, it appears that coal and nuclear are the most viable and wiil be discussed below.

\section{A. Coa1 Conversion}

The basic reactions for coal gasification and liquefaction are ei ther reaction with steam (water) or reaction with hydrogen.Generalizing the reactions:

water gasification $\quad \mathrm{C}+\mathrm{H}_{2} \mathrm{O}=\mathrm{CO}+\mathrm{H}_{2} \quad \mathrm{AH}=+42 \mathrm{kcal} / \mathrm{mol}$

direct hydrogenation $\mathrm{nC}+\mathrm{mH}_{2}=\mathrm{C}_{\Omega} \mathrm{H}_{2 \mathrm{~m}} \quad \Delta \mathrm{H}=$ Exothermic up to $-16 \mathrm{Kcal} / \mathrm{mol}$ for $\mathrm{CH}_{4}$ methane 
The $\mathrm{CO}$ and $\mathrm{H}_{2}$ formed in the endothermic watu gas reaction with coal can be used as a gaseous fuel itself (power gas) or can be converted by uumerous catalytic exothermic processes to various gaseous and IIquid fuels including methan (synthetic natural gas, SNG), methanol or hydrocarbon fuels (through high pressure Fischer-Tropsch type reactions).

$\begin{array}{llll}\text { For methane } & \mathrm{CO}+3 \mathrm{H}_{2} & =\mathrm{CH}_{4}+\mathrm{H}_{2} \mathrm{O} & \text { exothermic } \\ \text { For methanol } & \mathrm{CO}+2 \mathrm{H}_{2} & =\mathrm{CH}_{3} \mathrm{OH} & \text { exothermic } \\ \text { For hydrocarbons } & \mathrm{nCO}+2 \mathrm{nH}_{2} & =\left(\mathrm{CH}_{2}\right)_{\mathrm{n}}+\mathrm{nH}_{2} \mathrm{O} & \text { exothermic }\end{array}$
In order to provide the endothermic heat for the gasification reaction, usually coal itself is burned internally with oxygen in the gasifler. Thus, about 0.5 lbs of coal is burned per pound of coal converted to gas and on the basis of a carbon belance roughly the process is $66 \%$ efficient. The reactions proceed usually in the order of $1700^{\circ} \mathrm{F}$ and pressures up to 150 atmospheres. The problems of high temperature, high strength materials, and capacity of gasifier reactors becomes important.

B. Hybrid Cosl and Nuclear Conversion

1. The developers of the high temperature gas cooled reactor (HIGR) propose using nuclear process heat for the endothermic reactions to extend the supply of coal in conversion to liquid and gaseous fuels. However, as can be seen above, the most that coal can be extended is by $33 \%$ and cor this, reactors must: be made to operate at high termerature up to 1800 to $2000^{\circ} \mathrm{F}$ where nuclear materials problems and heat exchange proulems become very severe. The hazards of radioactivity and contamination become increasingly 1mportant at these elevated temperatures. Presently, conventional coal and gas fired gasiflers suffer from material rellability problems. The min benefit is that the nuclear heat is used efficiently 
and no power conversion cycles are necessary. I can understand why high temperature process heat reactors are being developed in Germany because of the limited supply of coal. In the U.S. where there is an abundant resource of coal these should be less of an incentive to employ high temperature reactors.

In the case of hydrogenation, this involves adding enough hydrogen to coal to liquify it to an oil or gasify it usually to methane (ANG). These reactions are usually exothermic and require little heat. However, hydrogen must be generated and this is usually obtained by water gasification of coal (the first reaction above). The Fossil Energy Division of ERDA is pursuing hydrogenation in many processes from light hydrogenation (Synthoil Process) to deep hydrogenation (i.e., Synthane and Flash HydroPyrolysis). Nuclear heat can also be applied to water gasification of other hydrocarbon containiag materials such as agricultural and urban waste. Nuclear energy can provide the hydrogen through electrolysis reactions as discussed below.

2. In addicion to providing high temperature nuclear heat for the coal gastfication system there is another hybrid nuclear fossil fuel process which is quite attractive.

The nuclear splitting of water (either electrolyois or thermal) can produce hydrogen and oxygen. Oxygen with water added can be used to gasify coal to $\mathrm{CO}$ and $\mathrm{H}_{2}$ and provide the endothermic heat of reaction and the hydrogen can be wsed to further hydrogenate coal or to produce methanol. 


$$
\begin{array}{ll}
\text { Electrolysis } & \mathrm{H}_{2} \mathrm{O}=\mathrm{H}_{2}+1 / 2 \mathrm{O}_{2} \\
\text { Gasification } & \mathrm{C}+\mathrm{H}_{2} \mathrm{O}=\mathrm{CO}+\mathrm{H}_{2} \\
\text { HI- cemp Energy } & 1 / 2 \mathrm{C}+\mathrm{I} / 2 \mathrm{O}_{2}=1 / 2 \mathrm{CO}_{2} \\
\text { Methanol Synthesis } & \mathrm{CO}+2 \mathrm{H}_{2}=\mathrm{CH}_{3} \mathrm{OH}
\end{array}
$$

This system can work with any carbon containing material, 1.e., coal, urban solid waste, agricultural products and wastes, etc. This is an attractive process because it combines the maximum utilization of carbon with the maximum utilization of nuclear anergy.

\section{Pure Nuclear Sources of Liguid and Gaseous Fuels}

Coal and other natural reduced forms of hydrocarbon suffer from polluting contaminants such as sulfur, trace elements, and ash. The synthesis of liquid and gaseous fuels using nuclear energy depends basicaIly on the decomposition of water and carbon dioxide by several different process as follows:
(a) Electrolysis

$$
\begin{aligned}
& \mathrm{H}_{2} \mathrm{O}=\mathrm{H}_{2}+1 / 2 \mathrm{O}_{2} \\
& \mathrm{H}_{2} \mathrm{O}=\mathrm{H}_{2}+1 / 2 \mathrm{O}_{2}
\end{aligned}
$$$$
\Delta \mathrm{H}=+68 \mathrm{Kcal} / \mathrm{coal}
$$
(b) High Temperature
Thermal Splitting

$$
\mathrm{CO}_{2}=\mathrm{CO}+1 / 2 \mathrm{O}_{2}
$$$$
\Delta \mathrm{H}=+68 \mathrm{Rcal} / \mathrm{coal}
$$
(c) Catalytic thermal in a cyclical process

$$
\mathrm{H}_{2} \mathrm{O} \quad \underset{\mathrm{Cu}, \mathrm{Mg}, \mathrm{Cl}_{2}}{\longrightarrow} \mathrm{H}_{2}+1 / 2 \mathrm{O}_{2}
$$
(d) Advanced systems
1) Radiation decomposition of $\mathrm{H}_{2} \mathrm{O}$ or $\mathrm{CO}_{2}$
2) Uitraviolet decomposition of $\mathrm{H}_{2} \mathrm{O}$ or $\mathrm{CO}_{2}$
3) Direct electrolytic decomposition of aqueous $\mathrm{K}_{2} \mathrm{CO}_{3}$ solution.

In the non-fossil nuclear system, the rats materials for synthetic fuels are $\mathrm{CO}_{2}$ and $\mathrm{H}_{2} \mathrm{O}$ and must come from readily available renewable sources such as alr, wher and earth. $\mathrm{CO}_{2}$ can be produced by calcination of limestone 
but this requires unearthing large amounts of stone, transportation expenditures and energy for its decomposition, all of which is environmentally unsound. This leaves water and air which are readily available most everywhere. The subject of extraction of $\mathrm{CO}_{2}$ from the air or from seawater is thus extremely important and is intensively examined in BNL 20016 at great length. The basic fuels produced by splitting water or $\mathrm{CO}_{2}$ are the gases hydrogen and carbon monoxide. These can be combined catalytically to form methane, methanol or hydrocarbons. The choice of process for production of hydrogen or carbon monoxide depends on a number of factors. The electroigsis of water is fiavored because it is a well-known technology and can yield high efficiencles (up to 85\%). It does require demonstration on a large scale. Ite main disadvantage is that it uses electrical energy. The high temperature splitting of wacer and $\mathrm{CO}_{2}$ requires extremely high temperature levels $\left(\sim 3000^{\circ} \mathrm{K}\right)$ with its attendent materials problem. CIR fusion reactors are more suitable for these processes than fission reactors. The catalytic thermal decompositios: of water has numerous disadvantages, including use of expens ive chemical materials such as hologen and metals which are subject to loss, handling of large masses of recycled chemicals, recycling thermal energy to make up heat balances, corrosion problems, etc., efficiencies usually run not more than 50\%. Advanced systems for CIR include high energy radiation interaction with $\mathrm{H}_{2} \mathrm{O}$ and $\mathrm{CO}_{2}$ in the blanket region. The direct electrolytic raduction of aqueous carbonate solution to hydrocarbon fuels is an intriguing possibility since it by passes the need for splitting $\mathrm{H}_{2} \mathrm{O}$ or $\mathrm{CO}_{2}$, and goes directly to hydrocarbons. This is the reason why we recoumend continuing the research and development on the application of CIR in this direct reduction area. 
It is our conclusion that the syetem we have proposed in BNL $20016(1,2)$ to utilize CIR energy to extract $\mathrm{CO}_{2}$ from the atmosphere and/or the ocean and combine or fix it with electrolytic hydrogen offers an advantageous alternative. It provides a non-fossil source of renewable liquid hydrocarbon fuels and feedstocks (for the petrochemical industry). It is an environmentally alean system (no sulfur, or trace metals). Furthermore, the estimates Indicate that capital investments are lower than future oil and coal investments. It eliminates the dcpendence on foreign ofl. of course, the syetem is not unique to fusion reactors; it can be applied to fission and fission-fusion systeme. However, the potentlal for fusion is a wore abundint, lower cost, cleaner nuclear exergy systen a id the ability to produce synthetic fuels extends its applicability several-fold. The anique features of fusion resctors for this purpose are the development of (1) the direct use of high energy radiation and (2) very high cemperature energy for water and carbon dioxide spiftting.

Some further words should be noted about hydrogen versus liquid hydrocarbon fuels (i.e., methanol) as synthetic fuels. Hydrogen gas is a good guacous fuel. However, it has disadvantages with respect so distribution, transportation, and storage. The metal hydride storage scheme reduces the problem with storage, however, distribution or getting it to end point users is a problem and the weight of the storage system is a Lfsadvantage. Furtherwore, hydrogen does not address ltaelf to the chemical feedstock problem. A source of carbon is required for this purpose. A supply of methanol solves this problem.

Finally, concerning the argument of an all-electric enconomy versua the need for synthetic fuels; the electric economy requires transisssion 
and storage. Transmission could be solved by superconducting 1ines; however, storage requires chemical or electrochemical devices such as batterles and fuel cells. Thus, we are in the chemical business anyway and there is really no such economy as an "all-electric economy." It should be noted that methanol is an excellent fuel for fuel cells so that if one wants to insist on an all-electris economy nomenclature, methanol is made by electrical power and can be considered as an energy carrfer for end use either thermal or electrical.

To sumberize, it is our belief that there is a definite long term necd for synthetic liquid hydrocarbon fuels. This will be supplied initially by coal conversion prccesses. Hybrid nuclear-coal systems for conversion of coal to synthetil: fuels will be based on supplying electrolytic hydrogen and oxygen using nuclear energy. Hybrid nuclearagricultural and nuclear-solid waste conversion to symthetic fuels wIII also involve supplying electrolytic hydrogen and oxygen. Finally, the nuclear-alr-water process for methanol synthesis provides a long-term altermitive to the above syatens and should be further developed, if for no other reason than to provide a strong competitive position in keeping the fossil finel sources of syrthetic tuels economically in line.

(1) Meyer Steinberg and V. D. Dang, "Use of Controlled Thermonuclear Reactor Fusion Power for the Prcducition of Synthetic Methanol Fuel from Air and Water," BarL 20016 (April 1975).

(2) S. Baron and M. Steinkerg, "The Economics of the Production of Liquid Fuel and Fertilizer by the Fixration of Atmospheric Carbon and Nitrogen Using Nuclear Power," BNL 20273. 